Research Article

\title{
The Effect of Time on the Activation of Bayah Natural Zeolite for Use in Palm Oil Shell Pyrolysis
}

\author{
Endang Suhendi*), Teguh Kurniawan, Adian Yoga Pradana, Vicky Zayan Giffari \\ Chemical Engineering Department, Engineering Faculty, Sultan Ageng Tirtayasa University, \\ Jalan Jendral Sudirman KM.3 Cilegon, Banten, Indonesia
}

Received: $8^{\text {th }}$ February 2021; Revised: 21st April 2021; Accepted: 21 ${ }^{\text {st }}$ April 2021

Available online: 24th April 2021; Published regularly: September 2021

\section{Abstract}

Oil palm shell (OPS) constitutes $60 \%$ of the waste generated during the processing of palm oil. However, OPS can potentially be converted into energy and chemicals through pyrolysis. The purpose of this study is to determine and analyse the effect of acid treatment time on the characteristics of natural zeolites, which were then applied to oil palm shell pyrolysis. The effect of the acid treatment time on the products of the pyrolysis was also studied. The acid treatment time was varied: 1,3 , and 5 hours. The crystallinity of the natural zeolites was determined by X-ray diffraction (XRD). Solid, liquid and gaseous pyrolysis products were observed. Proximate, ultimate, and heat analysis were performed on the solid product. The liquid product was characterised using gas chromatographymass spectrometry (GC-MS). Gas Chromatography (GC) was performed to analyse the composition of the gases produced. The results obtained from this study indicate that longer reflux times reduced the crystallinity of the zeolites. The addition of the zeolite catalysts increased the liquid products of pyrolysis from $24.5 \mathrm{wt} \%$ over the parent to $24.6-37.1 \mathrm{wt} \%$ over the acid-treated natural zeolites. The reduction of oxygenated compounds in bio-oil was observed in the amount of acetic acid and acetone produced.

Copyright (C) 2021 by Authors, Published by BCREC Group. This is an open access article under the CC BY-SA License (https://creativecommons.org/licenses/by-sa/4.0).

Keywords: oil palm shell; bio-oil; pyrolysis; catalyst; zeolite

How to Cite: E. Suhendi, T. Kurniawan, A.Y. Pradana, V.Z. Giffari (2021). The Effect of Time on the Activation of Bayah Natural Zeolite for Application of Palm Oil Shell Pyrolysis. Bulletin of Chemical Reaction Engineering \& Catalysis, 16 (3), 588-600 (doi:10.9767/bcrec.16.3.10313.588-600)

Permalink/DOI: https://doi.org/10.9767/bcrec.16.3.10313.588-600

\section{Introduction}

According to the Agency for Assessment and Application of Technology [1], energy needs in Indonesia increased continuously in 2016-2050 with an average GDP growth rate of $6.04 \%$ per year and population growth of $0.71 \%$ per year, resulting in a final energy growth rate of 5.3\% per year. With the demand for energy increasing every year, it is necessary to provide alternative renewable energy resources, such as bio-

* Corresponding Author.

Email: endangs.untirta@gmail.com (E. Suhendi) mass. Indonesia has a thriving plantation and agricultural sector, which has the potential to supply raw materials for making biomass. One rapidly growing source of biomass in Indonesia is palm oil. The Indonesian Palm Oil Association reports that the potential for biomass production in the Indonesian palm oil industry in 2018 will reach 9.46 million tons.

Palm oil processing not only produces palm oil but waste from it can also be used as a biomass product, which can be used as an alternative energy source. At present, oil palm shell waste is an under utilized resource. To process the oil palm shell, several methods can be used, one of which is pyrolysis. 
Pyrolysis is the process of thermally decomposing biomass at temperatures of $350-650{ }^{\circ} \mathrm{C}$ without involving the atmosphere or any other source of oxygen in the process [2]. The fast pyrolysis method is used because it can produce a large yield of bio-oil products, greater than $60 \%$. The pyrolysis method can also be used as an alternative process to generate liquid pyrolysis products, which can become fuel [3]. Bio-oil products from the pyrolysis process still have a high oxygen content from the obtained liquid properties. This makes it difficult to integrate bio-oil products into the existing oil process infrastructure. An increased number of routes for the exploitation of bio-oil products in the pyrolysis process is necessary. Processing by catalytic pyrolysis is therefore a technique of interest to improve the quality of bio-oil for use as fuel [4]. Kantarelis et al. [4] have used catalytic pyrolysis of biomass using a modified synthetic HZSM-5 zeolite catalyst to improve the quality of the liquid products with low oxygen content and increased coke formation [4]. Because the use of synthetic zeolites is relatively expensive, the use of natural zeolites in catalytic pyrolysis processes is of interest.

Natural zeolites are derived from rocks that have been changed by chemical and physical processes. Natural zeolite is obtained by mining products directly from nature, so they are cheaper than synthetic zeolites. However, natural zeolites have some weaknesses, such as inhomogeneous pore size, low catalytic activity and many impurities. In order to use these natural zeolites as catalysts, it is necessary to improve the zeolites. The dealumination process is one modification method that can be used to open zeolite pores by releasing aluminium from the open structure of zeolites using acids [5].

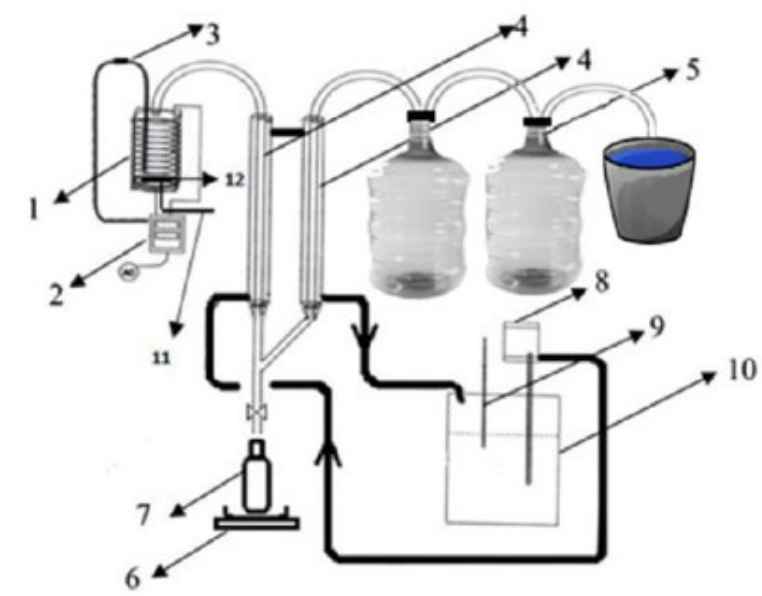

Figure 1. Experimental apparatus for pyrolysis
Acidification is a method that can remove impurities carried on the zeolite pores and improve catalyst performance.

According to the results of Kurniawan et al. [6], modification of natural zeolites using $1 \mathrm{M}$ hydrochloric acid $(\mathrm{HCl})$ with different times of hydrothermal recrystallisation $(2,14$, and $26 \mathrm{~h}$ ) showed increased hydrothermal recrystallization with high zeolite crystallinity. Treatment using mild concentrations of acid and short hydrothermal duration will retain the zeolite framework. The crystallinity of zeolites is directly proportional with other variables, such as micropore surface area, mesopores, $\mathrm{Si} / \mathrm{Al}$ ratio and the acidity of zeolite [6]. Wibowo and Lestari have suggested the application of natural zeolites modified with different concentrations $(0.5,1,1.5$, and $2 \mathrm{M})$ of sulfuric acid $\left(\mathrm{H}_{2} \mathrm{SO}_{4}\right)$ to the pyrolysis process. The use of 1 $\mathrm{M}$ sulfuric acid increased the $\mathrm{Si} / \mathrm{Al}$ ratio and produced a high yield of bio-oil. Research with similar methods using zeolites as a catalyst for the pyrolysis process is rarely reported [7].

The aim of this research is to extend the studies that have been conducted by Wibowo and Lestari, focusing on the determination of the effect of the duration of refluxing with $1 \mathrm{M}$ sulfuric acid as the catalyst activation process on the characteristics of natural zeolites and the effects on the characteristics of the pyrolysis products.

\section{Materials ad Methods}

This research consisted of two stages, the zeolite activation stage and the pyrolysis stage. The first stage of this research is the activation of the natural zeolite using $1 \mathrm{M} \mathrm{H}_{2} \mathrm{SO}_{4}(98 \%$, Merck) with a reflux time of $1 \mathrm{~h}$ (BNZ-1), $3 \mathrm{~h}$ (BNZ-3) and $5 \mathrm{~h}$ (BNZ-5). The second stage is the pyrolysis of OPS with the addition of the zeolite catalyst at $500{ }^{\circ} \mathrm{C}$.

\subsection{Materials}

The materials used in this research were OPS waste which was obtained from PTPN VI Malingping, Bayah. Natural zeolites were obtained from Bayah District, Banten, Indonesia.

\subsection{Equipment}

The equipment used in this research included a set of reflux devices for zeolite activation and a set of pyrolysis tools for the pyrolysis process. A set of pyrolysis tools is shown in Figure 1. Figure 1 shows the parts of the pyrolysis apparatus: (1) reactor, (2) temperature 
control, (3) pipe, (4) double pipe condenser, (5) gas reservoir, (6) analytical balance sheet, (7) fluid collector, (8) coolant pump, (9) thermometer, (10) coolant water tank, (11) nitrogen flow pipes, (12) nitrogen flow sealers.

\subsection{Zeolite Activation}

The type of catalyst used in this research was Bayah natural zeolite (BNZ), which was obtained from the zeolite mining area in Bayah, Lebak Regency, Indonesia. Up to $100 \mathrm{~g}$ of zeolite was crushed and screened to obtain a material size of $-10+14$ mesh. After the catalyst preparation was completed, the sample was refluxed using $1000 \mathrm{~mL}$ of $1 \mathrm{M} \mathrm{H}_{2} \mathrm{SO}_{4}$ for 1,3 and $5 \mathrm{~h}$ at a temperature of $90{ }^{\circ} \mathrm{C}$. Then the sample was rinsed using distilled water until the $\mathrm{pH}$ of the sample was neutral. After that, the sample was dried at room temperature for $24 \mathrm{~h}$. Furthermore, the sample was dried in an oven at a temperature of $110^{\circ} \mathrm{C}$ for $1 \mathrm{~h}$ to remove the remaining water content of the sample. After that, the sample was calcined for $6 \mathrm{~h}$ at a temperature of $500{ }^{\circ} \mathrm{C}$ to remove the anions on the surface of the catalyst. Finally, the zeolite sample was placed in a desiccator. Some of the activated zeolites were characterized using XRD and used as catalysts in the pyrolysis process.

\subsection{Pyrolysis Process}

The raw material used in this research is oil palm shell (TKS) from PTPN VI Malingping that has been detached from its skin and dried in sunlight to reduce the water content. The dried TKS was crushed into $5-10 \mathrm{~mm}$ sized particles, and $200 \mathrm{~g}$ aliquots were prepared. After the raw material preparation process was complete, the TKS was first pyrolyzed without using a catalyst. In this study, five pyrolysis variations were used, namely: without a catalyst, with activated natural zeolite (BNZ-0) catalysts, and with natural Bayah zeolite catalysts activated for different durations $1 \mathrm{~h}$ (BNZ-1), 3 $\mathrm{h}$ (BNZ-3) and $5 \mathrm{~h}$ (BNZ-3). Furthermore, the system was cooled using a double pipe condenser at a temperature of $18-20^{\circ} \mathrm{C}$. The reactor is heated gradually to a temperature of $500{ }^{\circ} \mathrm{C}$ and kept constant for $1 \mathrm{~h}$. The volatile gases were condensed into a liquid product in the condenser, which is weighed every $3 \mathrm{~min}$. The pyrolysis process was carried out at atmospheric pressure. The reaction was considered to begin $(0 \mathrm{~min})$ after the desired pyrolysis conditions were reached.

\subsection{Characterization of the Zeolite}

The zeolites were characterized by their crystallinity and morphology before and after activation. The zeolite crystallinity analysis was carried out using a Rigaku Smartlab $3 \mathrm{~kW}$ X-ray diffractometer (XRD) at the LIPI Physics Laboratory, Serpong, Tangerang, Indonesia.

\subsection{Characterization of Pyrolysis Products}

The characterization of pyrolysis products includes the analysis of the solid (char), liquid (bio-oil) and gas products. The proximate content of the raw materials and the solid products were analyzed using the Leco TGA-601 thermogravimetric analyzer, while the ultimate content of the raw materials and the solid products were analyzed using the Leco CHN2000 analyzer, both of which were used at the Research and Development Center for Mineral and Coal Technology, Bandung, Indonesia. The liquid products of pyrolysis were characterized using an Agilent 5973 gas chromatographymass spectrometer (GC-MS) at the Police Headquarters Forensic Laboratory, Duren Sawit, East Jakarta, Indonesia. The gaseous products of pyrolysis were characterized using a Shimadzu 8A TCD detector gas chromatograph (GC) at the RPKA Laboratory of the Department of Chemical Engineering, University of Indonesia, Depok, Indonesia.

\section{Results and Discussion}

\subsection{Characteristics of Zeolites}

Zeolite is a hydrated aluminosilicate mineral containing alkali and alkaline earth metals in a 3-dimensional framework. Minerals in zeolites have interesting physical and chemical properties, including absorbing organic and inorganic substances and can be used as cation exchangers and catalysts [8]. Natural zeolites are generally poor in crystallinity, have nonuniform pore sizes, high numbers of impurities and low catalytic activity. Therefore an activation or modification treatment is needed before the zeolite is used. Acid, hydrothermal, calcination, oxidation and impregnation treatments have been shown to increase the $\mathrm{Si}$ to $\mathrm{Al}$ ratio, surface area and acidity of zeolites [9].

Table 1 shows that the longer the time taken to activate the zeolite, the more mass is lost, most likely because the crystal structure is damaged by the dealumination process. Not only $\mathrm{Al}$ is extracted: other metals, such as $\mathrm{Fe}$, $\mathrm{K}$ and $\mathrm{Ca}$, will also be extracted during acid treatment. Figure 2 shows that the zeolites 
used in this study were dominated by mordenite. Impurities were also observed in the XRD patterns, which were identified as clinoptilolite. Ismettulloh et al. [10] have also conducted an XRD analysis on the Bayah natural zeolites and reported mordenite, clinoptilolite, heulandite and quartz phases [10].

Figure 2 shows that the natural zeolite parent (BNZ-0) and the natural zeolite activated with $1 \mathrm{M} \mathrm{H}_{2} \mathrm{SO}_{4}$ for $3 \mathrm{~h}$ (BNZ-3) produce different XRD patterns. There was a decrease in intensity in the BNZ-0 sample compared to BNZ-3. The diffraction peaks of BNZ-0 are $2 \theta=$ $11.14^{\circ}, 13.04^{\circ}, 16.88^{\circ}, 19.02^{\circ}, 22.28^{\circ}, 25.99^{\circ}$, $26.79^{\circ}, 28.08^{\circ}, 29.93^{\circ}$, and $31.91^{\circ}$ and all peak heights decreased in the BNZ-3 sample. The addition of $\mathrm{H}_{2} \mathrm{SO}_{4}$ to the zeolite activation process causes the process of dealumination ( $\mathrm{Al}$ that comes out of the zeolite framework). Similar research has been done by Suhendi et al. [7] who used an acid treatment that decreased the XRD intensity of the zeolite framework because of dealumination. The separation of $\mathrm{Al}$ atoms from the zeolite structure framework can cause decrystallisation, an increase in irregular crystal structure, which reduces crystallinity [9]. This is also in accordance with a study conducted by Lestari [11] in which the process of dealumination of natural zeolites using $\mathrm{HCl}$ and HNO3 damaged crystal structures [11]. The acid treatment of natural zeolites caused the loss of zeolite crystallinity, and the decrease of crystallinity led to a decrease in the number of acid sites, which was determined by py-FTIR spectroscopy and $\mathrm{NH}_{3}$-TPD. Furthermore, aluminium was extracted during the acid treatments as indicated by the XRF analysis [6].

Figure 2 shows that some peaks $\left(10.01^{\circ}\right.$, $13.47^{\circ}, 17.37^{\circ}, 20.6^{\circ}$ and $27.63^{\circ}$ ) in the diffraction spectrum of $\mathrm{BNZ} 3$ had high intensities compared to those of the BNZ-0 sample. The in-

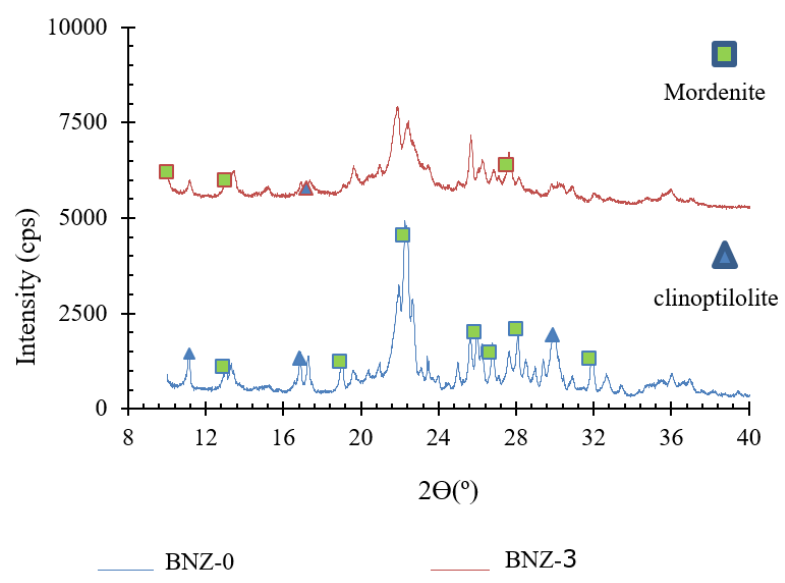

Figure 2. XRD patterns of BNZ-0 and BNZ-3. creased intensity of several peaks is possibly due to metal oxide impurities that exchange with the cation $\mathrm{H}^{+}$on the zeolite surface, making the surface clean from impurities. The zeolite surface becomes more open so that the $\mathrm{X}$-ray beam is completely diffracted by the zeolite surface and not blocked by impurities, and thus the intensity becomes high, and the crystallinity is high. Zeolites with mordenite phases can be used as catalysts, adsorbents and ion exchangers because the cavities and channels in zeolites with mordenite phases have pores large enough $(+7 \AA)$ to be used as metal carriers [12].

\subsection{Pyrolysis Temperature and Mass Profile}

According to Basu [2], the pyrolysis process

has been divided into four stages based on their thermal properties. The first stage was the drying stage, which takes place at a temperature of $\sim 100^{\circ} \mathrm{C}$. As can be seen in Figure 3, the pyrolysis process in this study was initiated at a temperature of $\sim 35-100{ }^{\circ} \mathrm{C}$, which took place between minutes 0 and 6 , and it was called the drying stage. During the initial phase of heating, the biomass at these low temperatures, moisture and some bound water are released through the pores and surface of the biomass. The moisture on the surface of the biomass (free moisture) evaporated. This causes a decrease in char mass and an increase in biooil and gas masses [2]. As shown in Figure 3, there is a decrease in char mass and an increase in the gas mass starting in the 9th minute and an increase in bio-oil mass in the 12 th minute of the process.

Furthermore, the initial stage of the pyrolysis process takes place at a temperature between 100 and $300{ }^{\circ} \mathrm{C}$. Figure 3 shows that the initial stage of the pyrolysis process in this study occurred at the 6th minute range. At this stage, exothermic biomass dehydration occurs with the release of low molecular weight water and gases such as $\mathrm{CO}$ and $\mathrm{CO}_{2}$ [2]. This is caused by hemicellulose undergoing structural cracking (degrading). The main component in hemicellulose is xylan, which is the most un-

Table 1. The change of zeolite mass before and after the activation process.

\begin{tabular}{ccc}
\hline $\begin{array}{c}\text { Acid Treatment } \\
\text { Time (h) }\end{array}$ & $\begin{array}{c}\text { Mass Before } \\
\text { Activation }(\mathrm{g})\end{array}$ & $\begin{array}{c}\text { Mass After } \\
\text { Activation }(\mathrm{g})\end{array}$ \\
\hline 1 & 100 & 78.4 \\
3 & 100 & 71.4 \\
5 & 100 & 65.6 \\
\hline
\end{tabular}


stable compound and easily undergoes hydrolysis and dehydration. The degradation of xylan produces eight compounds: water, methanol, formic acid, acetic acid, propionic acid, hydroxy1-propanone, hydroxy-1-butanone and 2 -furfuraldehyde [13].

The intermediate stage, also referred to as primary pyrolysis, takes place at temperatures $>200{ }^{\circ} \mathrm{C}\left(200-600{ }^{\circ} \mathrm{C}\right)$. As can be seen in Figure 3 , the intermediate stage occurs at the $9^{\text {th }} \mathrm{mi}$ nute in samples with catalysts and in the $12^{\text {th }}$ minute in samples without a catalyst. Most of the steam and bio-oil is produced at this stage [2] due to the process of evaporation of most of the volatile substances, which is referred to as devolatilization [14]. This stage results in the decomposition of the large molecules of biomass particles into charcoal (primary charcoal), condensable gas (steam and bio-oil) and noncondensable gas [2]. This is consistent with the results of this study in Figure 4, where, at this stage, there is a decrease in char mass and an increase in the mass of bio-oil and gas. The biooil mass increased between the $12^{\text {th }}$ and $54^{\text {th }}$ minutes, after which the value obtained is constant. The gas mass increased between the $9^{\text {th }}$ and $27^{\text {th }}$ minutes then the longer the mass produced will be increasingly reduced for a decrease in char mass starting in the $9^{\text {th }}$ minute. At this stage, there is also a thermal decomposition process, in which cellulose will form levoglucosan through the depolymerization process. The cellulose dehydrated, decarbonated, and produced $\mathrm{C} 2, \mathrm{C} 3$, and $\mathrm{C} 4$ compounds. The volatile compounds come from the biomass due to the thermal decomposition process. Furthermore, the cellulose underwent a cracking reaction (degradation) so that carboxyl compounds and oxygenated compounds were produced.

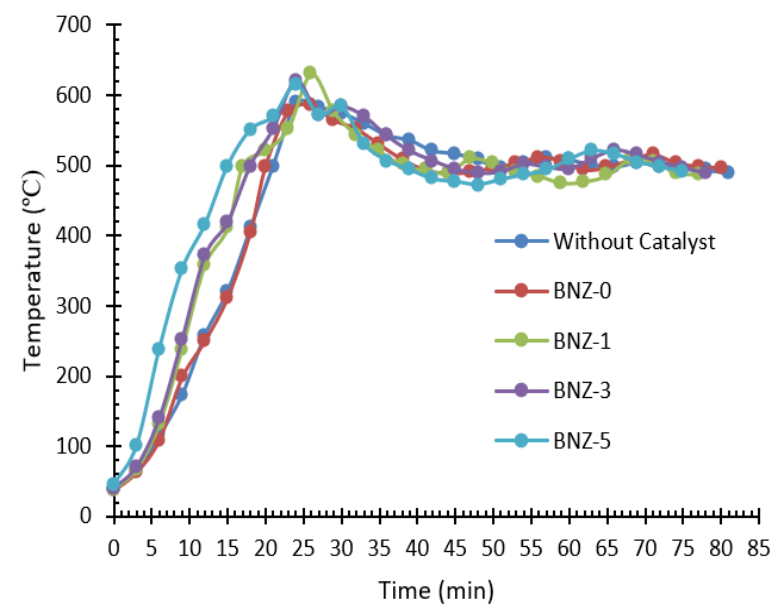

Figure 3. Temperature profiles of oil palm shell with various variations.
Meanwhile, the lignin was dehydrated, depolymerized and carbonized, then it was thermally degraded into phenols, formic acid, $\mathrm{CO}_{2}$ and water [14].

The final stage of pyrolysis occurs at temperatures of $\sim 300-600{ }^{\circ} \mathrm{C}$. As seen in Figure 3, the final stage in this study occurred at the $9^{\text {th }}$ minute for the BNZ-5 catalyst, the $12^{\text {th }}$ minute for BNZ-0, BNZ-1 and BNZ-3, and the $15^{\text {th }} \mathrm{mi}-$ nute for the catalyst-free sample. This final stage involved the secondary cracking of volatiles into char, gas (non-condensable gas), and bio-oil (condensable gas). If the component remained in the biomass long enough, the condensable gas with large molecular weights could be broken down, producing additional char (secondary char) and gas. However, if the condensable gas was removed quickly from the reaction site, it condensed to produce tar and bio-oil. Higher pyrolysis temperatures support hydrogen production, which will increase rapidly at $\sim 600^{\circ} \mathrm{C}$. This rapid increase is because, at this stage, long hydrocarbon chains break into short hydrocarbon chains. Then a reaction will occur between the primary cracking molecules, such as the reaction between $\mathrm{CO}$ and water, which produces $\mathrm{H}_{2}$ and $\mathrm{CO}_{2}$, which will react to $\mathrm{CH}_{4}[2]$.

In the final step of pyrolysis, the temperature was kept constant at $500{ }^{\circ} \mathrm{C}$ for 60 minutes. This released compounds that remained in the biomass. In Figure 4, at temperatures of $\sim 500-600{ }^{\circ} \mathrm{C}$ between the $15^{\text {th }}$ and $26^{\text {th }}$ minutes, the mass of the gas continued to increase due to the occurrence of secondary volatile cracking [2]. Unlike the gas products, at this final stage, the bio-oil mass continued to decrease. This is because the bio-oil mass has formed at a temperature of $500{ }^{\circ} \mathrm{C}$.

In Figure 4, the profile of the liquid and gas products increases with the solid products. The use of catalysts accelerated the breakdown of long chain hydrocarbons into short chain hydrocarbons. The gas production is faster than without the use of catalysts. This is in accordance with the research of Kumara, who has used zeolite catalysts in the pyrolysis of mahogany wood powder. The use of zeolite catalysts has increased the reaction rates, accelerated the breakdown of the hydrocarbon chains and accelerated the distribution of the pyrolysis products [15].

BNZ-1 most likely provided greater access to the acid sites for molecules during pyrolysis. Despite the reduced crystallinity of BNZ-1, the sample probably had much larger pore sizes after acid treatment. As a result, the mass transfer through the diffusion mechanism was high- 
er than for the zeolites that had not been treated with acid. However, the longer acid treatment led to a sharp decline in the zeolite crystallinity and reduced the number of acid sites as well. It can be seen in BNZ-5 (Figure 4e) that the pyrolysis rate became slower than that of BNZ-1.
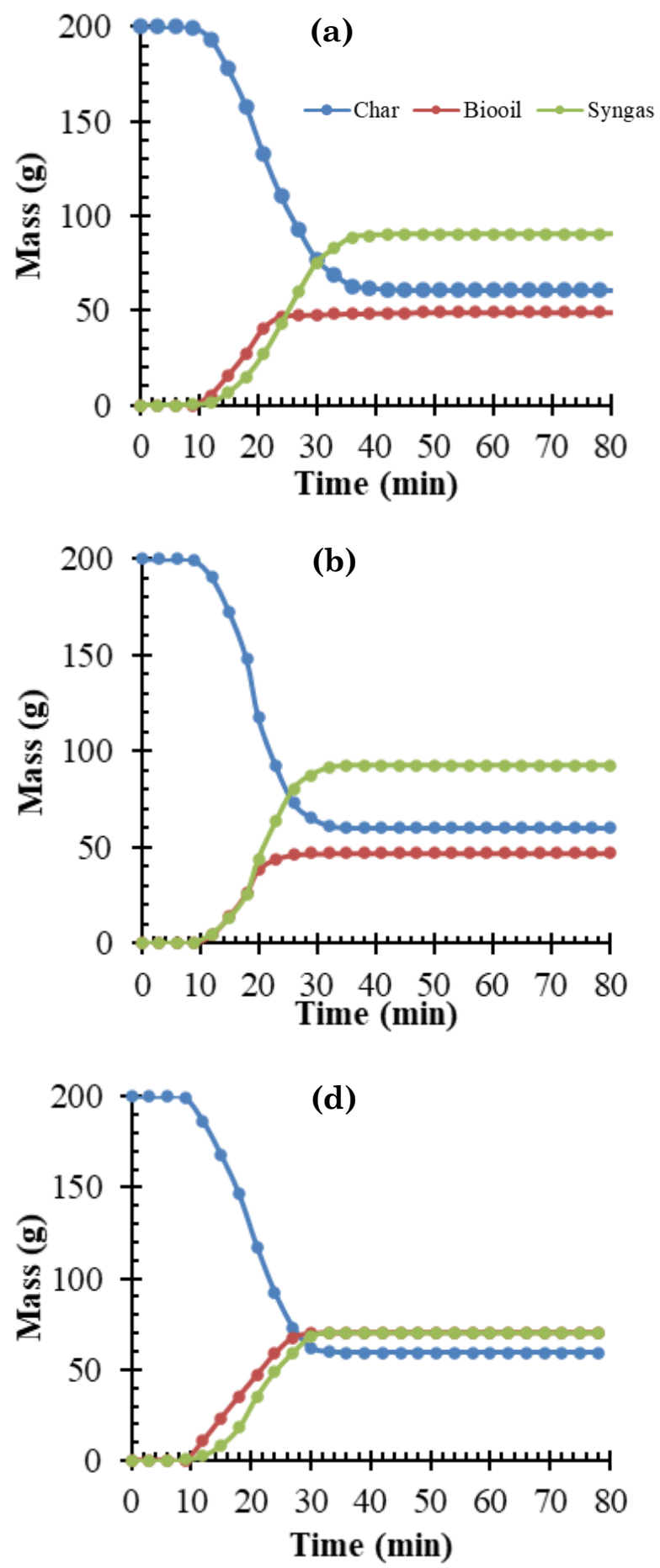

\subsection{Product Distribution}

The solid yield was obtained from weighing the solid contained in the combustion reactor. Liquid yields were obtained from the condensation of vapor accommodated in the liquid outlet: the output was measured and the mass of the liquid weighed. In contrast, the gas yield is obtained from the amount of water in a container that is displaced by the gas formed in the pyrolysis process. This is called the water displacement principle; that is, the volume of gas formed is considered to be the same as the volume of water that is removed.

Table 2 shows the product distribution data from the non-catalytic and catalytic pyrolysis processes. The yield of gas produced was higher than the solid and liquid yields. This result is different to that of Suhendi et al. [16], whose pyrolysis process has used zeolite that had been treated with acid and resulted in a higher production yield of liquid than solid and gas. A higher yield of liquid can happen because the more condensable vapor was produced than
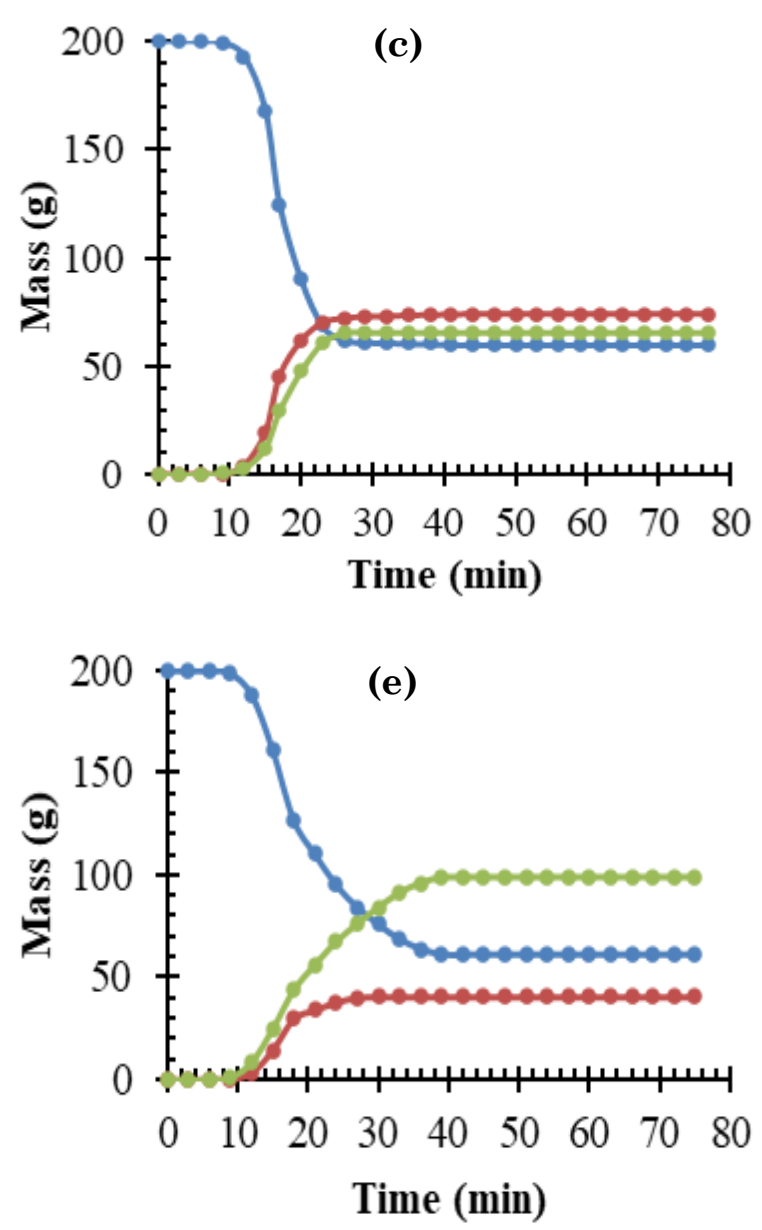

Figure 4. Pyrolysis product mass profile; (a) Non-Catalytic, (b) BNZ-0, (c) BNZ-1Hour, (d) BNZ-3, (e) BNZ-5. 
non-condensable vapor and solids. In this research, the pyrolysis process using modified zeolite catalysts produced more non-condensable vapor than condensable vapor and solids. The different results in this research were caused by different application of acid, which produced differing pore sizes.

The yield of solid products did not change significantly in the catalytic and non-catalytic pyrolysis processes, and remained in the range of $\sim 29.56-30.47 \mathrm{wt} \%$. Santiyo et al. [17] observed a similar result, where catalytic and non-catalytic pyrolysis did not significantly influence the resulting solid product. The largest solid product formation occurred in pyrolysis without the use of catalysts with the production of $30.47 \mathrm{wt} \%$ solid products and the smallest formation occurred with the use of BNZ-3, which yielded $29.56 \mathrm{wt} \%$. The magnitude of the distribution of solid yield products in the noncatalyzed pyrolysis process is due to the absence of secondary cracking as a result of the use of zeolites which facilitated reactions such as cracking.

In Table 2, it can be seen that the distribution of liquid product yields is variable at 20.7$37.09 \mathrm{wt} \%$. The formation of liquid products in catalytic and non-catalyzed pyrolysis fluctuated. In the non-catalyzed pyrolysis process, the yield of liquid products was $24.55 \mathrm{wt} \%$, and increased with the use of BNZ-0 to 24.62 wt\%. The yield increased again with the use of BNZ-1 to $37.09 \%$, which then decreased with the use of BNZ-3 and BNZ-5 to $35.26 \mathrm{wt} \%$ and $20.22 \mathrm{wt} \%$, respectively (Table 4). From the data in Table 2, the highest liquid product yield data is obtained from the pyrolysis process using BNZ-1 with a yield of $37.09 \mathrm{wt} \%$ and the lowest liquid product yield is from the pyrolysis process using BNZ-5, at $20.22 \mathrm{wt} \%$.

In Table 2, there is an increase in liquid product yields during the catalytic pyrolysis process compared to the non-catalytic pyrolysis process. The addition of catalysts to the process of pyrolysis of OPS has been proven to increase the amount of liquid product yield compared to the process of pyrolysis without the use of catalysts. This is similar to the research conducted by Sukarjo [18], in that catalysts allowed reactions to take place more quickly or allowed reactions at lower temperatures due to changes that the catalysts trigger in reagents. In another study, Ates et al. [19] have also experienced an increase in liquid product yield due to the unstable hydrocarbon component reacting to produce excess liquid products rather than forming short chain hydrocarbons (C1-C4). The most significant increase in this work occurred with the use of BNZ-1 and BNZ-3 catalysts and experienced a drastic reduction when BNZ-5 was used. This proves that activating BNZ by using a $1 \mathrm{M} \mathrm{H}_{2} \mathrm{SO}_{4}$ solution and varying the activation time has different effects on the liquid products. The decrease in liquid product yield is due to the large number of noncondensable gas products formed, which produces more light hydrocarbon fractions in the cracking process that cannot be condensed [20].

In Table 2, the distribution of gas product yields is $32.44-49.35 \mathrm{wt} \%$. The gas production data in Table 2 has increased in catalytic pyrolysis using BNZ without activation and BNZ- 5 but decreased with the use of BNZ-1 and BNZ-3. In general, the addition of zeolite as a catalyst reduced the volume of liquid products due to the hydrocarbon cracking process enhanced by the zeolite catalyst. The cracking process breaks the long chain hydrocarbons into short chain hydrocarbons. Thus, some short chain hydrocarbon compounds enter the gas phase and have a boiling point lower than the ambient temperature [21]. However, in this study, the yield of gas products decreased with the use of BNZ-1 and BNZ-3. The same thing has been done by Kim, where the gas product yield has decreased with the use of an E-paint type catalyst because the liquid and solid yields increased [22]. In this study, the decrease in gas product yield was caused by the absence of secondary cracking because the pores on the surface of the catalyst have been covered by coke so that condensable steam cannot diffuse to the active center of the catalyst.

Table 2. Product distribution.

\begin{tabular}{cccc}
\hline Variation & Solid $(\% \mathrm{wt})$ & Liquid $(\% \mathrm{wt})$ & Gas $(\% \mathrm{wt})$ \\
\hline Without Catalyst & 30.47 & 24.555 & 44.975 \\
BNZ-0 & 30.065 & 24.625 & 45.685 \\
BNZ-1 & 29.97 & 37.09 & 32.44 \\
BNZ-3 & 29.565 & 35.265 & 35.17 \\
BNZ-5 & 29.95 & 20.7 & 49.35 \\
\hline
\end{tabular}




\subsection{Char Characterizations}

In this study, pyrolysis experiments were carried out by comparing the pyrolysis process without a catalyst to pyrolysis using natural zeolites without activation (BNZ-0) and pyrolysis with natural zeolites activated with $1 \mathrm{M}$ $\mathrm{H}_{2} \mathrm{SO}_{4}$ for $3 \mathrm{~h}$. In Table 3 , the distribution of char products does not change significantly even with the addition of a catalyst to the pyrolysis process.

In Table 3, the proximate and ultimate analysis results are given as follows:

\section{a. Moisture content}

The biomass contained two kinds of water content: inherent moisture, or free water from the biomass and free moisture, or water that sticks to the surface of the biomass [23]. High water content in biomass charcoal can reduce the usefulness and quality of the charcoal. The main effect of the high water content is a decrease in the calorific value when burning. Conversely, if the water content in the charcoal decreases, then it will increase the heating value.

The process of pyrolysis can affect the water content of charcoal. In Table 3 , the ratio of moisture in raw materials is $21 \mathrm{wt} \%$ to 1.82 $3.77 \mathrm{wt} \%$ for non-catalytic pyrolysis and catalytic pyrolysis, respectively. In the pyrolysis process, there is a decrease in the moisture content of the pyrolysis charcoal product. The decrease in the moisture content of the biomass is caused by the $500{ }^{\circ} \mathrm{C}$ heating process during pyrolysis, which resulted in the loss of some of the moisture content in the biomass due to the thermal process in the pyrolysis process. This outcome is in accordance with the data obtained by Damanik et al. [24]: in their study, the pyrolysis process can reduce the value of the moisture content in char products, which is $21 \mathrm{wt} \%$ in raw materials to $3.77-6.18 \mathrm{wt} \%$ after the pyrolysis process. From the data obtained, the lowest moisture value, of $1.82 \mathrm{wt} \%$, from the catalytic pyrolysis variation using BNZ-3.

\section{b. Ash Content}

Ash is the residue from the combustion process, which is in the form of minerals that do not contain carbon. The main components of ash are silica, aluminium, iron and calcium, and there are small amounts of magnesium, titanium, sodium and potassium [2]. In Table 3, the raw material had an ash content of 2.21 $\mathrm{wt} \%$, which increased after the catalytic and non-catalytic pyrolysis to between 5.28-5.78 wt $\%$. The highest ash content, 5.78 wt $\%$, was found following pyrolysis without catalysts and catalytic pyrolysis using zeolites without activation. The increased ash content of palm shell charcoal possibly occurred due to the formation of mineral salts and other particles because of carbon oxidation during the pyrolysis process [23].

\section{c. Volatile Matter}

Volatile matter content plays a role in providing the flame capability of a biomass. The amount of the volatile matter content will affect the quality of the biomass charcoal. Volatile matter consists of liquid or condensable vapor (mainly water, organic and lipids) and a small portion of gases or non-condensable vapor $\left(\mathrm{CO}\right.$ and $\left.\mathrm{CO}_{2}\right)$ [25]. In Table 3, it can be seen that the volatile matter content in the raw material is $69.19 \mathrm{wt} \%$, which rose to $10.88-$

Table 3. Analysis results of raw materials and pyrolysis products.

\begin{tabular}{cccccc}
\hline \multirow{2}{*}{ Analysis } & \multirow{2}{*}{ Unit } & \multirow{2}{*}{ Raw Material } & \multicolumn{3}{c}{ Variation } \\
\cline { 4 - 6 } & & & Without Catalyst & BNZ-0 & BNZ-3 \\
\hline Moisture & \%wt (adb) & 21 & 3.77 & 2.16 & 1.82 \\
Ash Content & \%wt (adb) & 2.21 & 5.29 & 5.78 & 5.74 \\
Volatile Matter & \%wt (adb) & 69.19 & 12.77 & 12.26 & 10.88 \\
Fixed Carbon & \%wt (adb) & 18.91 & 78.17 & 79.80 & 81.56 \\
Heat & cal/g (adb) & 4437 & 7258 & 7392 & 7498 \\
$\mathrm{C}$ & \%wt (adb) & 55.40 & 81.96 & 80.12 & 83.22 \\
$\mathrm{H}$ & \%wt (adb) & 6.50 & 3.18 & 2.66 & 2.82 \\
$\mathrm{~N}$ & \%wt (adb) & 0.5 & 0.74 & 0.88 & 0.87 \\
$\mathrm{O}$ & \%wt (adb) & 38.60 & 8.72 & 7.392 & 7.498 \\
$\mathrm{~S}$ & \%wt (adb) & 0.10 & 0.11 & 0.04 & 0.04 \\
\hline
\end{tabular}


$12.76 \mathrm{wt} \%$ after catalytic and non-catalytic pyrolysis. The reduction in volatile matter content in palm shell charcoal products shows that the palm shell has been converted to a liquid or gas product during the pyrolysis process. The greatest decrease occurred in the catalytic pyrolysis process using BNZ-3, which had a volatile content of $10.88 \mathrm{wt} \%$. A reduction in volatile matter levels was also obtained by Suhendi et al. [16], who pyrolyzed OPS using catalysts activated with $\mathrm{HCl}$ solution for 1,3 and $5 \mathrm{~h}$ with the volatile matter of the raw material equaling $69.45 \mathrm{wt} \%$ and the experiments using catalysts had results in the range of 14.41$19.53 \mathrm{wt} \%$. Our use of activated zeolite shows that the use of catalysts has an effect in reducing the content of volatile matter in the oil palm shell charcoal.

\section{d. Fixed Carbon}

Fixed carbon can be expressed as the amount of carbon contained in the material that remains after the volatile matter content is removed. Fixed carbon is the main content of a solid fuel. The fixed carbon content plays an important role in determining the heating value of a solid fuel. The greater the fixed carbon content is, the higher the heating value of the solid fuel is [25]. In Table 3, the fixed carbon values vary across the samples; the fixed carbon content of the raw material is $18.91 \mathrm{wt} \%$, which rose to $78.17-81.56 \mathrm{wt} \%$ after catalytic and non-catalytic pyrolysis. There was an increase in the fixed carbon content after the pyrolysis process, which occurred along with the decrease in the moisture content and volatile matter in biomass. The higher the fixed carbon content of a biomass is, the higher the heating value of the biomass is.

\section{e. Caloric Value}

The heating value is the energy content or heat released from a combustion process. Generally, the heating value the main parameter used to determine the quality of a fuel. Table 3 shows the calorific value of the raw material before the pyrolysis process was $4437 \mathrm{cal} / \mathrm{g}$, which increased to $7258-7498 \mathrm{cal} / \mathrm{g}$ after the catalytic and non-catalytic pyrolysis processes. The high heat value after the pyrolysis process is influenced by the carbon content and ash content. The higher the carbon content, the higher the calorific value, while a higher ash content reduces the calorific value [26].

\section{f. Carbon (C)}

The carbon content in this study increased as shown in Table 3, where the content in the raw materials was $55.40 \mathrm{wt} \%$ and this rose to 80.12-83.22 wt\% after the catalytic and noncatalytic pyrolysis processes. The increase in carbon content in charcoal products is caused by the release of the water content and volatile substances during the pyrolysis process [27].

\section{g. Hydrogen $(\mathrm{H})$}

The hydrogen content in this study decreased, as shown in Table 3, with the raw material containing $6.50 \mathrm{wt} \%$, which dropped to 2.82-3.18 wt\% after the catalytic and noncatalytic pyrolysis processes. The decrease in hydrogen levels in charcoal products is due to the decomposition of hydrogen and volatile matter, which evaporate on the cellulose and lignin components to form bio-oil products such as hydrocarbon cracking and gas products (non-condensable gas), including water, methane and $\mathrm{H}_{2}$ [27].

\section{h. Oxygen $(\mathrm{O})$}

The oxygen content in this study decreased, as shown in Table 3, with the raw material containing $38.60 \mathrm{wt} \%$, which rose to $7.392-8.72$ $\mathrm{wt} \%$ after the catalytic and non-catalytic pyrolysis processes. A decrease in oxygen content in charcoal products can be caused by the combustion reactions that occur during the pyrolysis process, which produces oxygen that primarily reacts with carbon content (C) [24].

\section{i. Nitrogen (N) and Sulfur (S)}

The nitrogen content in this study experienced an insignificant increase (Table 3) from $0.5 \mathrm{wt} \%$ for the raw material to $0.74-0.88 \mathrm{wt} \%$ after the catalytic and non-catalytic pyrolysis process. In contrast, the sulfur content experienced a decrease and an insignificant increase (Table 3) with an initial value of the raw material of $0.10 \mathrm{wt} \%$, which changed to $0.04-0.11$ $\mathrm{wt} \%$ after the catalytic and non-catalytic pyrolysis processes. Low nitrogen and sulfur contents will reduce the amount of NOx and SOx gas emissions from biomass combustion [14]. Low nitrogen and sulfur content can be expected because the majority of palm oil waste, including OPS, is cleaner and more environmentally friendly than coal [28]. 


\subsection{Bio-Oil Characterization}

The composition of bio-oil is very complex, but in general, it contains water, organic matter, and a small amount of pyrolysis ash. Organic compounds in bio-oil include alcohols, furans, phenols, aldehydes and organic acids. Bio-oil is a mixture of aqueous and nonaqueous phases, as shown in Figure 5. The aqueous phase contains low molecular weight oxygenated organic compounds, whereas the non-aqueous phase contains high molecular weight oxygenated compounds, aromatic compounds and polycyclic aromatic hydrocarbons [29]. The low viscosity layer is a product of the decomposition of cellulose and hemicellulose, while the lower layer, which has a low viscosity, is a high molecular weight substance derived from lignin [29].

Acetic acid is a major component of the acids in bio-oil formed due to the deacetylation reaction of hemicellulose [30]. Acetic acid in bio-oil increases the $\mathrm{pH}$ value and increases the corrosive nature of the bio-oil. In this work, the acetic acid content was reduced by the addition of catalysts from $46.06 \%$ for the raw material to $40.1 \%, 45.86 \%, 37.2 \%$ and $42.07 \%$ for the sample with a non-activated catalyst, BNZ-0, BNZ-1, BNZ-3 and BNZ-5, respectively. This is due to the decarboxylation reaction, which breaks the carboxylic chain group. This finding is in accordance with the research of Wibowo and Lestari [7], which compared the results of non-catalytic and catalytic pyrolysis of palm kernel shells, which reduced acetic acid levels from $48 \%$ to $42.59 \%$, respectively, by using the Bayah natural zeolite as a catalyst.

The addition of a catalyst also caused a decarbonylation reaction, that is, termination of the carbonyl group from the molecular structure. This can be seen from the decreased amount of acetone produced $(0-1.22 \%)$ compared to that produced in non-catalytic pyroly-

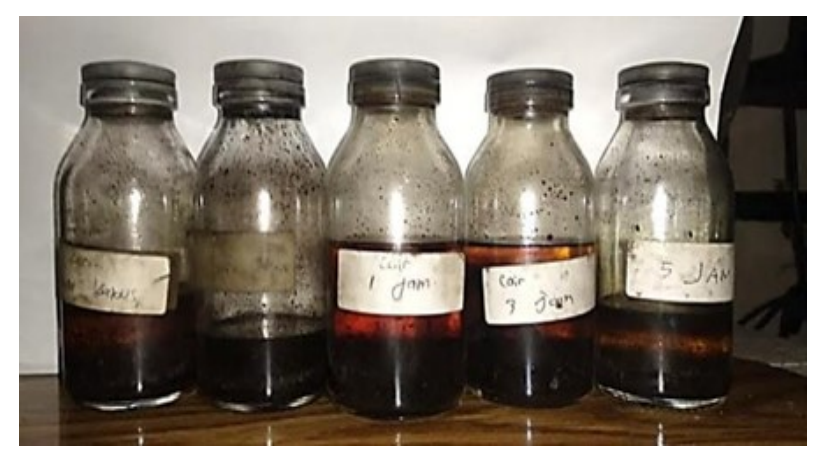

Figure 5. Pyrolysis liquid product (bio-oil), variation from left to right: without a catalyst, BNZ-0, BNZ-1, BNZ-3, BNZ-5. sis $(1.37 \%)$. The termination of the carbonyl group in ketones will result in the formation of $\mathrm{CO}$ gas. In addition, the loss of ketone groups in bio-oil products can also be caused by the oxidation of ketone groups to acetic acid compounds. This happened in the work of Alfikri [31], which carried out the pyrolysis of oil palm shell without catalyst, with non-activated catalyst and catalyst activated with $0.5 \mathrm{M}, 1 \mathrm{M}, 1.5$ $\mathrm{M}$ and $2 \mathrm{M} \mathrm{HCl}$ solutions and yielded ketone contents of $5.94 \%, 5.04 \%, 1.47 \%, 1.61 \%, 1.8 \%$ and $0.9 \%$ respectively.

Lignin is one of the biggest constituent elements of biomass. The phenol component found in bio-oil is a product of lignin depolymerization and cracking reactions [30]. The amount of phenol in pyrolysis products without catalyst (39.31\%) increased with the addition of nonactivated or activated catalysts (43.81$47.82 \%)$. The increased levels of phenols in biooil were due to the increased amount of lignin that was decomposed by the presence of catalysts in pyrolysis. Increased phenol levels in bio-oil also occur in the research of Wibowo and Lestari [7], where the results of non-catalytic bio-oil pyrolysis, with non-activated catalysts, as well as with catalysts activated with $0.5,1$, 1.5 and $2 \mathrm{M} \mathrm{H}_{2} \mathrm{SO}_{4}$ solutions, yields improvements of $40.31 \%, 40.83 \%, 47.47 \%, 43.90 \%$, $45.94 \%$, and $45.57 \%$, respectively.

\subsection{Gas Characterization}

The oxygen content in bio-oil lowers the $\mathrm{pH}$, making the oil acidic and unfit for use because of its corrosive properties. Therefore, the oxygenated compounds must be removed. The composition of the gas products resulting from OPS pyrolysis, as shown in Figure 6, was dominated by $\mathrm{CO}$ and $\mathrm{CO}_{2}$, which were $30--52 \%$ and $25-64 \%$, respectively. The dominance of $\mathrm{CO}$ and $\mathrm{CO}_{2}$ in pyrolysis gas products also occurred in the study conducted by Adam et al. [32], which pyrolyzed palm oil leaves using a variety of catalysts. The $\mathrm{CO}_{2}$ content in gas products is produced by several reaction routes.

The removal of oxygen content in carboxylic acids in bio-oil to form $\mathrm{CO}_{2}$ is called decarboxylation [29]. Without using a catalyst, the $\mathrm{CO}_{2}$ content produced was $53 \%$, whereas with the use of non-activated catalysts and catalysts activated in 1,3 , and 5 hours, the $\mathrm{CO}_{2}$ levels produced were $51.43 \%, 64.52 \%, 51.21 \%$, and $25.16 \%$, respectively. The decreasing $\mathrm{CO}_{2}$ levels can be explained by the formation of other gases, such as $\mathrm{CO}$ and $\mathrm{H}_{2}$. The reduction in $\mathrm{CO}_{2}$ levels has also been observed by Atnaw et 
al. [33], who have studied the process of gasification of palm oil leaves at varying temperatures. As can be seen from the graph, decreased $\mathrm{CO}_{2}$ levels along with increasing levels of $\mathrm{CO}$, $\mathrm{CO}_{2}$ and $\mathrm{CH}_{4}$ products are seen, due to the reduction of the oxygen content of the bio-oil by using a catalyst. Adam et al. [32], who pyrolyzed raw pine wood with various catalysts, have also observed the same effect.

In this study, the amount of HHV in each sample ranged from 9-18 $\mathrm{MJ} / \mathrm{Nm}^{3}$ (Figure 7). The highest $\mathrm{HHV}$ value was in the gas products of BNZ-5, $18.63 \mathrm{MJ} / \mathrm{Nm}^{3}$, because $\mathrm{CO}_{2}$ gas products are formed in line with the increases in $\mathrm{H}_{2}, \mathrm{CO}$ and $\mathrm{CH}_{4}$. The estimated value of $\mathrm{HHV}$ in pyrolysis gas products ranged between 11-20 $\mathrm{MJ} / \mathrm{Nm}^{3}$ [8]. The $\mathrm{HHV}$ value obtained in this study is greater than that obtained in the research conducted by Kim et al. [22], who conducted research on palm shells using a noncatalytic pyrolysis method with pyrolysis temperatures below $500{ }^{\circ} \mathrm{C}$, with resulting average $\mathrm{HHV}$ values of $4-8 \mathrm{MJ} / \mathrm{Nm}^{3}$. The use of a catalyst and the optimum pyrolysis temperature increased the HHV value of the gas product

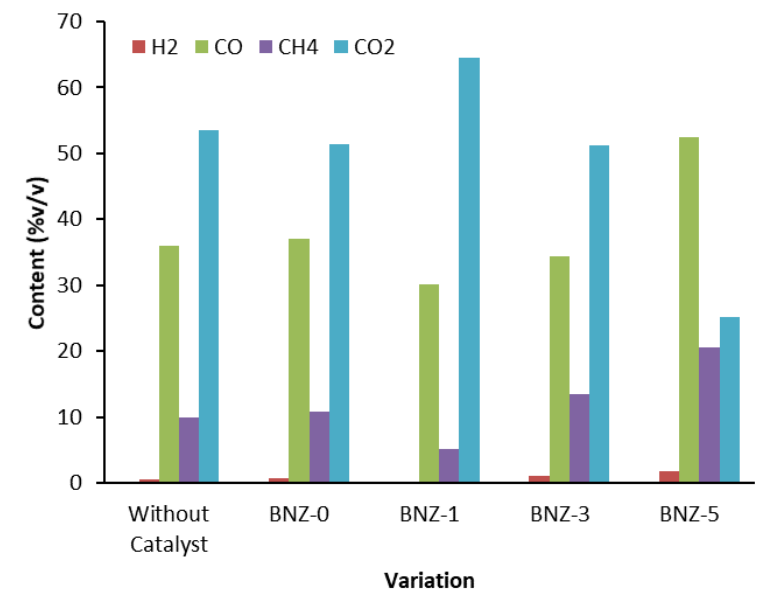

Figure 6. Composition of pyrolysis gas products.

\section{Conclusion}

Some conclusions that can be drawn from this research are that acid treatment of natural zeolites will damage the crystal structure of the zeolites, and the longer the duration of the treatment the less zeolite mass is left in the final modification. The use of activated natural zeolite catalyst for pyrolysis decreased the oxygen levels of bio-oil due to the thermal decomposition reactions. In addition, the use of activated natural zeolite catalysts increases $\mathrm{CO}$, $\mathrm{CH}_{4}$, and $\mathrm{H}_{2}$ gas levels with decreasing $\mathrm{CO}_{2}$. However, no significant effect of activated natural zeolite on the solid product was observed.

\section{Acknowledgements}

We thank Sultan Ageng Tirtayasa University for funding this research in the internal grant program for associate lecturers in 2020.

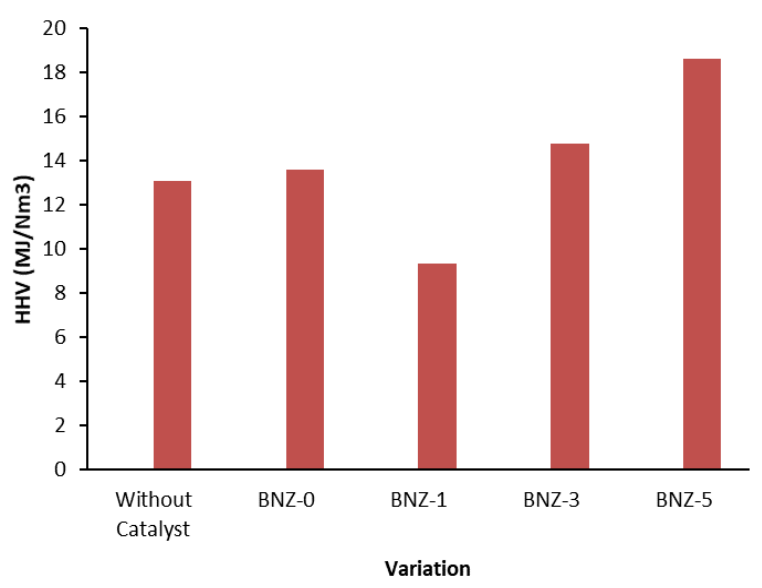

Figure 7. HHV values of pyrolysis gas products

Table 4. Liquid product analysis results (bio-oil).

\begin{tabular}{lccccc}
\hline Compound & Without Catalyst & BNZ- 0 & BNZ- 1 & BNZ- 3 & BNZ- 5 \\
\hline Acetone (2-Propanon) & 1.37 & 1.22 & - & 1.19 & - \\
Acetic Acid & 46.06 & 40.1 & 45.86 & 37.2 & 42.07 \\
Propanoic Acid & 1.32 & - & - & 2.11 & - \\
2-Furancaboxaldehyde & 1.08 & 0.96 & - & 0.96 & - \\
Phenol & 39.31 & 46.89 & 47.02 & 43.83 & 43.81 \\
Pyridine & 1.59 & 1.51 & - & 1.56 & 2.1 \\
1,2 - Benzenediol & 7.24 & 7.08 & 7.12 & 13.14 & 9.4 \\
5,4'-Dimethoxy-2-methylbibenzyl & - & 2.25 & - & - & - \\
\hline
\end{tabular}




\section{References}

[1] Anonym. 2018. Outlook Energi Indonesia (2018). Jakarta: Badan Pengkajian dan Penerapan Teknologi.

[2] Basu, P. (2010). Biomass Gasification and Pyrolysis: Practical Design and Theory. United Kingdom : Elsevier.

[3] Shemfe, M.B., Gu, S., Ranganathan, P. (2010). Techno-Economic Performance Analysis of Biofuel Production and Miniature Electric Power Generation from Biomass. Fast Pyrolysis and Bio-Oil Upgrading. Fuel. 143, 361-372. DOI: 10.1016/j.fuel.2014.11.078

[4] Kantarelis, E, Yang, W., Blasiak, W. (2014). Effect of Zeolite to Binder Ratio on Product Yields and Composition during Catalytic Steam Pyrolysis of Biomass over Transition Metal Modified HZSM5. Fuel, 122, 119-125. DOI: 10.1016/j.fuel.2013.12.054

[5] Nasser, G.A., Kurniawan, T., Tago, T., Bakare, I.A., Taniguchi, T., Nakasaka, Y., Masu da, T., Muraza, O. (2016). Cracking of NHexane Over Hierarchical MOR Zeolites Derived From Natural Minerals. Journal of The Taiwan Institute of Chemical Engineers. 61, 20-25. DOI: 10.1016/j.jtice.2015.11.025

[6] Kurniawan, T., Muraza, O., Bakare, I.A., Sanhoob, M.A., Al-Amer, A.M. (2018). Isomerization of n-Butane over Cost-Effective Mordenite Catalysts Fabricated via Recrystallization of Natural Zeolites. Industrial \& Engineering Chemistry Research, 57, 1894-1902. DOI: 10.1021/acs.iecr.7b04040

[7] Suhendi, E., Wibowo, A., Lestari, T., Kurniawan, T. (2020). Effect of acid concentration on the Activation of Bayah Natural Zeolite for Palm Kernel Shell Pyrolysis Application. Reaktor, 20(3), 109-116. DOI: 10.14710/reaktor.20.3.109-116

[8] Barthomeuf, D., Imelik, B., Naccache, C., Coudurier, G., Taarit, Y.B., Vedrine, J.C., (1985). Catalysis by Acids and Bases, Amsterdam: Elsevier.

[9] Pardoyo, L., Darmawan, A. (2009). Pengaruh Perlakuan $\mathrm{HCl}$ pada Kristalinitas dan Kemampuan Adsorpsi Zeolit Alam Terhadap Ion $\mathrm{Ca}^{2+}$. Laboratorium Kimia Organik, JurnalSains dan Matematika, 17(2), 100-104. Oct. 2010.

[10] Ismettulloh, M., Gumelar, F., Nuryoto, N., Kurniawan, T. (2019). Modifikasi Zeolit Alam Bayah Menggunakan Asam dan Pengaplikasiannya dalam Pengurangan Amonium Pada Kolam Ikan Bandeng. Jurnal Integrasi Proses, 8(1), 7-13. DOI: 10.36055/jip.v8i1.5506
[11] Lestari, D.Y. (2010). Kajian Modifikasi dan Karakterisasi Zeolit Alam dari Berbagai Negara. Yogyakarta: Universitas Negeri Yogyakarta (UNY).

[12] Trisunaryati, W., Triyono, T., Fibrina, D. (2003). Pembuatan katalis Ni-Mo/Mordenit dengan variasi rasio $\mathrm{Mo} / \mathrm{Ni}$ dengan karakterisasinya untuk konversi asam stearat. Indonesian Journal of Chemistry, 2003, 3(2), 80-90.

[13] Syakir, M., Allolerung, D., Poeloengan, Z., Syafruddin, Rumini, W. (2010). Budidaya Kelapa Sawit. Bogor: Aska Media.

[14] Ningrum, A.O. (2011). Proses Pembuatan Bio-oil dari Limbah Kelapa Sawit (Tandan, Tempurung dan Serat) untuk Bahan Bakar Alternatif dengan Metode Fast Pyrolisis. Skripsi. Depok : Universitas Indonesia.

[15] Kumara, D.C., Wijayanti, W., Widyanuriyawan, D. (2015). Pengaruh Penggunaan Katalis (Zeolit) Terhadap Kinetic Rate Tar Hasil Pirolisis Serbuk Kayu Mahoni (Switenia Macrophylla). Jurnal Rekayasa Mesin, 6(1) 1925. DOI: 10.21776/ub.jrm.2015.006.01.3.

[16] Suhendi, E., Naibaho, P.P.U., Fauzan, E.R., Kurniawan, T. (2020). Pyrolisis of Palm Kernel Shell to Chemicals by Using Bayah Natural Zeolites. Jurnal Bahan Alam Terbarukan, 9(1), 61-68, DOI: 10.15294/jbat.v9i1.22250

[17] Wibowo, S., Efiyanti, L., Pari, G. (2017). Characterization of Palm Fruit Empty Bunches Bio-oil with the Addition of Ni/NZA Catalyst Using Free Fall Pyrolisis Method. Jurnal Penelitian Hasil Hutan, 35(2), 83-100. DOI: 10.20886/jphh.2017.35.2.83-100.

[18] Sukarjo. (1997). Kimia Fisika. Jakarta: PT Rineka Cipta.

[19] Ates, F., Ayse, E.P., Putun, E. (2004). Fixed Bed Pyrolysis of Euphorbia Rigida With Different Catalysts. Energy Conversion and Management 46, 421-432, DOI: 10.1016/j.enconman.2004.03.011

[20] Yunanda, I.Y., Bahri, S., Saputra, E. (2016). Pirolisis Kulit Kayu Pinus Merkusii Menjadi Bio-oil Menggunakan Katalis Mo/Lempung Cengar. JOM FTEKNIK, 3(1) Februari 2016. Universitas Riau.

[21] Junaidi, H.F. (2012). Uji Aktivitas dan Selektivitas Katalis Ni/H5NZA dalam Proses Hidrorengkah Metil Ester Minyak Kelapa Sawit (MEPO) Menjadi Senyawa Hidrokarbon Fraksi Pendek. Thesis. URL : http://repository.unej.ac.id/handle/123456789/ 9941: Universitas Jember.

[22] Kim, S.W., Koo, Bon S., Lee, Dong Hyun. (2014). Catalytic Pyrolisis Of Palm Kernel Shell Waste In Fluidized Bed. Bioresource Technology 167, 425-432, DOI: 10.1016/j.biortech.2014.06.050. 
[23] Sukandarrumidi. (2006). Batubara dan Pemanfaatannya. Pengantar Teknologi Batubara Menuju Lingkungan Bersih. Gadjah Mada University Press.

[24] Damanik, R., Nurdianto, S. (2017). Pirolisis Tempurung Kelapa Sawit. Skripsi. Universitas Sultan Ageng Tirtayasa.

[25] Pestano, L.D.B., Jose, W.I. (2016). Production of Solid Fuel by Torrefaction Using Coconut Leaves as Renewable Biomass. International Journal of Renewable Energy Development 5(3), 187-197. DOI: 10.14710/ijred.5.3.187197.

[26] Loppies, J.E. (2016). The Characteristics of Cocoa Pod Husk Charcoal Produced in Various Pyrolysis Conditions. Jurnal Industri Hasil Perkebunan, 11(2), 105-111.

[27] Raju, M., Armansyah, H.T., Radite, P.A.S. (2016). Karakteristik Arang dan Gas-gas Hasil Pirolisis Limbah Kelapa Sawit. Jurnal Keteknikan Pertanian, 4(2),153-160. DOI: 10.19028/jtep.04.2.\%25p.

[28] Sukiran, M.A., Abnisa, F., Daud, W.M., Bakar, N.A., Loh, S.K. (2017). A Review of Torrefaction of Oil Palm Solid Wastes for Biofuel Production. Energy Conversion and Management, 149 , $101-20$. D O I : 10.1016/j.enconman.2017.07.011
[29] Bridgwater A.V., Banks, S.W. (2016). Chapter 14: Catalytic fast pyrolysis for improved liquid quality. Aston University, Birmingham, United Kingdom.

[30] Irvantino, B., Wahyuni, S., Saputro, S.H. (2013). Preparasi Katalis Ni/Za dengan Metode Sonokimia Untuk Perengkahan Katalitik Polipropilen dan Polietilen. Indonesian Journal of Chemical Science, 2(2), DOI: 10.15294/ijcs.v2i2.1598

[31] Alfikri, N., Nuru, I.J. (2019). Pengaruh Penggunaan Katalis Pada Proses Pirolisis Cangkang Kelapa Sawit. Thesis. Universitas Sultan Ageng Tirtayasa. Indonesia.

[32] Adam, J., Antonakou, A., Lappas, A., Stocker, M., Nilsen, M.H., Bouzga, A., Hustad, J.E., Oye, G. (2006). In situ catalytic upgrading of biomass derived fast pyrolysis vapours in a fixed bed reactor using mesoporous materials. Microporous and Mesoporous Materials, $96(1-3), \quad 93-101$. D O I : https://doi.org/10.1016/j.micromeso.2006.06.0 21

[33] Atnaw, S.M., Sulaiman, S.A., Yusup, S. (2013). Syngas production from downdraft gasification of oil palm fronds. Energy, 61, 491-501. DOI: 10.1016/j.energy.2013.09.039.

Selected and Revised Papers from $3^{\text {rd }}$ International Conference on Chemistry, Chemical Process and Engineering 2020 (IC3PE 2020) (https://chemistry.uii.ac.id/ic3pe/) (Universitas Islam Indonesia (UII), Labuan Bajo, Nusa Tenggara Timur, Indonesia by 30 ${ }^{\text {th }}$ September - $1^{\text {st }}$ October 2020) after Peer-reviewed by Scientific Committee of IC3PE 2020 and Peer-Reviewers of Bulletin of Chemical Reaction Engineering \& Catalysis. Editors: I. Istadi; Is Fatimah 